\title{
Chitosan-Phenylalanine Nanoparticles (Cs-Phe Nps) Extend the Postharvest Life of Persimmon (Diospyros kaki) Fruits under Chilling Stress
}

\author{
Fahimeh Nasr $^{1}$, Mirian Pateiro ${ }^{2} \mathbb{D}$, Vali Rabiei ${ }^{1}\left(\mathbb{D}\right.$, Farhang Razavi $^{1} \mathbb{D}$, Steven Formaneck $^{3} \mathbb{D}^{\mathbb{D}}$, \\ Gholamreza Gohari ${ }^{4, *(1)}$ and José M. Lorenzo ${ }^{2,5, *(D)}$
}

1 Department of Horticulture, Faculty of Agriculture, University of Zanjan, Zanjan 45371-38791, Iran; fahimenasr53@yahoo.com (F.N.); rabiei@znu.ac.ir (V.R.); razavi.farhang@znu.ac.ir (F.R.)

2 Centro Tecnológico de la Carne de Galicia, Avd. Galicia n ${ }^{\circ}$ 4, Parque Tecnológico de Galicia, San Cibrao das Viñas, 32900 Ourense, Spain; mirianpateiro@ceteca.net

3 Department of Operations and Supply Chain Management, Faculty of Management, Canadian University Dubai, Dubai 117781, United Arab Emirates; steven.formaneck@cud.ac.ae

4 Department of Horticulture, Faculty of Agriculture, University of Maragheh, Maragheh 83111-55181, Iran

5 Área de Tecnología de los Alimentos, Facultad de Ciencias de Ourense, Universidad de Vigo, 32004 Ourense, Spain

* Correspondence: gohari.gh@maragheh.ac.ir (G.G.); jmlorenzo@ceteca.net (J.M.L.)

Citation: Nasr, F.; Pateiro, M.; Rabiei V.; Razavi, F.; Formaneck, S.; Gohari, G.; Lorenzo, J.M

Chitosan-Phenylalanine

Nanoparticles (Cs-Phe Nps) Extend the Postharvest Life of Persimmon (Diospyros kaki) Fruits under Chilling Stress. Coatings 2021, 11, 819. https://doi.org/10.3390/ coatings11070819

Academic Editors: Elena Torrieri and Jaejoon Han

Received: 4 June 2021

Accepted: 5 July 2021

Published: 7 July 2021

Publisher's Note: MDPI stays neutral with regard to jurisdictional claims in published maps and institutional affiliations.

Copyright: (c) 2021 by the authors Licensee MDPI, Basel, Switzerland. This article is an open access article distributed under the terms and conditions of the Creative Commons Attribution (CC BY) license (https:// creativecommons.org/licenses/by/ $4.0 /)$

\begin{abstract}
There are high levels of damage imposed on persimmon fruit postharvest, especially after storing it in cold storage, which causes chilling injury (CI). To reduce this stress on the fruit, the conventional way is to use chemical treatments. Since there is a limitation in the use of chemical materials, it is necessary to apply non-harmful treatments to decrease chilling injury and maintain the quality of persimmon in cold storage. The aim of this study is to investigate the effects of chitosan-loaded phenylalanine nanoparticles (Cs-Phe NPs) $(2.5$ and $5 \mathrm{mM})$ on physiochemical and quality factors of persimmon (Diospyros kaki) during 45 days of storage at $4{ }^{\circ} \mathrm{C}\left(38^{\circ} \mathrm{F}\right)$ and evaluate the impact of Cs-Phe NPs on the preserving quality in order to reduce the chilling injury of this fruit. The experiment was conducted using a completely randomized design with three replications. Treatments were applied at 15,30 , and 45 days after storage at $4{ }^{\circ} \mathrm{C}$ with $\geq 90 \%$ relative humidity. The size of Cs-Phe NPs was less than $100 \mathrm{~nm}$, approximately. The results showed that application of $5 \mathrm{mM}$ of Cs-Phe NPs delayed the negative effects of chilling stress and enhanced antioxidant capacity, firmness, and total soluble solids of persimmon fruit. Lower $\mathrm{H}_{2} \mathrm{O}_{2}$ and malonaldehyde (MDA) accumulation along with higher soluble tannin and total carotenoid accumulation in persimmon fruit treated with $5 \mathrm{mM}$ Cs-Phe NPs was also observed. Fruit coated using Cs-Phe NPs in both concentrations (2.5 and $5 \mathrm{mM}$ ) showed the highest antioxidant enzyme activity for superoxide dismutase (SOD), catalase (CAT), and ascorbate peroxidase (APX) and the lowest for polyphenol oxidase (PPO) and chilling injury during storage. According to our results, $5 \mathrm{mM}$ of Cs-Phe NPs could be considered as the best treatment under chilling-stress conditions.
\end{abstract}

Keywords: antioxidant enzymes; chilling index; nanotechnology; post-harvest conditions; shelf life

\section{Introduction}

Cold storage is an effective postharvest technology to maintain the quality and to extend the marketing span of most horticultural crops. However, persimmon, as one of the most economically important subtropical fruits, is sensitive to chilling injury (CI) developed during low temperature storage. The major symptoms of chilling injury in persimmon fruit are flesh softening and gelling, external browning, loss of fruit flavor, compacted flesh areas, and internal browning, depending on the cultivar [1,2]. Recently, various methods such as modified atmospheres packaging and controlled atmospheres (CA) storage $[3,4]$, application of hot water [5], hot air [6], 1-methylcyclopropene (1-MCP) [7], short-term high 
$\mathrm{CO}_{2}$ [8] and combined treatment of 1-MCP with controlled atmosphere (CA) [9], oxalic acid [10], and gibberellic acid [11] have been used by researchers for alleviating postharvest CI symptoms.

Application of semi-permeable coatings, for instance, chitosan, has been shown to enhance the stability of fresh horticultural products such as persimmon. Chitosan is a cationic polysaccharide with high molecular weight that is soluble in dilute organic acids and can be used for coating fruits [12]. The chitosan coating is biologically safe and can be used instead of chemical antifungal substances $[13,14]$. The presence of hydroxyl and amine groups in the structure of chitosan allows it to be synthesized in nano size and combined with other materials $[12,15]$. Chitosan nanoparticles have more advantages than conventional chitosan, as in nano shape the surface-to-volume ratio were increased in comparison with the conventional type, which gradually occurs with decreasing particle size, increases the activity of the particles, and thus increases their effectiveness $[16,17]$.

The phenylalanine as an amino acid used for the biosynthesis of all phenolic compounds via the phenylpropanoid pathway. In recent years, the application of exogenous phenylalanine has gained much attention for use as a biologically safe molecule for postharvest quality maintenance of many horticulture crops $[18,19]$. Phenylalanine treatment has been reported to alleviate chilling injury of plum fruit during cold storage by maintaining membrane integrity and improving reactive oxygen species (ROS) scavenging capacity. Treated fruit showed higher 2,2-diphenyl-1-picrylhydrazyl (DPPH) scavenging capacity by enhancing phenolic compounds accumulation and antioxidant enzyme activity [19]. In buckwheat sprouts, Seo et al. [20] showed that the exogenous application of L-phenylalanine $(0.5 \mathrm{mM})$ was the optimum concentration for the synthesis of total and individual phenolic compounds. Pre-harvest application of phenylalanine in grape fruits increased the accumulation of phenolic compounds, including anthocyanin and flavonoids [21]. Pre-harvest or postharvest application of phenylalanine has also been suggested as an eco-friendly and healthy strategy to enhance fungal decay resistance in mango, avocado, strawberry, and citrus fruits during postharvest life [18].

In recent years, nanotechnology has had a wide range of applications in horticultural products. Nanocomposite is one of the incomparable techniques for enhancing the solubility and retention time of bioactive compounds on fruits and vegetables. The nano chitosan has wide application in the control of plant diseases, increasing shelf life and preserving quality in pre- and postharvest [22]. Chitosan nanoparticles can significantly enhance postharvest life, decrease weight loss and increase total soluble solid (TSS) and quality in banana fruits [23]. In another study chitosan combined with cellulose nanoparticles had positive effects on strawberry fruit by decreasing weight loss and enhancing antioxidant compounds in comparison with chitosan treatment during 21 days of cold storage [24]. Meena et al. [25] reported that $\mathrm{Cu}$-chitosan nanoparticle treatment successfully maintained qualitative and quantitative characteristics such as maintaining firmness, preventing decrease of titrable acidity, ascorbic acid, lycopene, and phenolic compound, and preventing increased decay in tomato fruit by inducing increase antioxidant system activity and many desirable physico-chemical characteristics of nanoparticles during 21 days of storage.

Utilizing chitosan nanoparticles instead of chitosan and phenylalanine alone due to the higher surface-volume ratio, higher activity particles, and higher effectiveness is more demanding. In accordance with previous reports, we hypothesized that chitosanfunctionalized phenylalanine nanoparticles (Cs-Phe NPs) would positively affect quality maintenance of persimmon fruits and reduce chilling injury. In that context, the present study was designed to investigate the effects of Cs-Phe NPs on persimmons' quality attributes and the physiological and biochemical characteristics susceptible to chilling injury (CI). 


\section{Materials and Methods}

\subsection{Preparation of Cs-Phe NPs}

Chitosan-coated phenylalanine nanoparticles were prepared at Maragheh University as follows. The materials for this project are completely natural and are prepared from Novin Shimyar Company with registration number 178068. Chitosan, phenylalanine, and triphosphate are major consumables. First, chitosan was dissolved well with acetic acid under the influence of temperature. Then, a certain amount of phenylalanine was dissolved in distilled water and added to the chitosan. Tri-polyphosphate (TPP) was dissolved in distilled water at a certain volume ratio and added dropwise to the mixture of chitosan and phenylalanine. The precipitate obtained under the freeze-drying process lead to the preparation of its powder. After the sample was dried, the general techniques of Scanning Electron Microscope (SEM), Transmission Electron Microscopy (TEM), Fourier Transform Infrared Spectroscopy (FT-IR), and X-Ray Diffraction (XRD) were used for examination and identification.

\subsection{Fruit Samples}

The experiment was conducted in the horticulture laboratory of the Faculty of Agriculture, University of Zanjan, Zanjan, Iran. Persimmon fruits at the yellow-orange maturity stage ( $70 \%-80 \%$ surface yellow coloration development and the total soluble solids equal $15.75 \%$ ), of the same size and shape, and healthy and free of infections were selected and harvested from an orchard at Karaj, Iran ( $35^{\circ} 35^{\prime} 50.6^{\prime \prime} \mathrm{N}$ and $\left.50^{\circ} 58^{\prime} 56.7^{\prime \prime} \mathrm{E}\right)$.

\section{Fruit Treatments}

On the day of harvest, a sample of 15 fruits was randomly selected and tested for initial physical and chemical properties. Other samples were prepared for the application of chitosan (1\%), phenylalanine ( $5 \mathrm{mM})$, and Cs-Phe NPs (2.5 and $5.0 \mathrm{mM})$ treatments and control (distilled water). Fruit was dipped in $10 \mathrm{~L}$ of solution containing treatments for $20 \mathrm{~min}$. Fruits were dried at ambient temperature for about $60 \mathrm{~min}$. Then, fruits were stored at $4 \pm 0.5^{\circ} \mathrm{C}$ and $\geq 90 \%$ relative humidity for 45 days. Following 15,30 , and 45 days of storage, 15 fruits were sampled for each treatment. Before measurement of quantitative and qualitative characteristics, fruits were kept at $25^{\circ} \mathrm{C}$ for $24 \mathrm{~h}$ (as a shelf life).

\subsection{Quantitative and Qualitative Measurements}

\subsubsection{Chilling Injury (\%)}

Chilling injury was based on protocol presented by Ding et al. [26]. Five samples were randomly selected from each treatment to experiment chilling index symptoms based on the percentage of texture, skin browning, and fruit texture jelling. The degree of chilling injury was showed on a rating of 0 to 4 stage: 0 as (no symptoms), 1 ( $<25 \%$ has symptoms), 2 ( $25 \%-50 \%$ has symptoms), 3 ( $50 \%-75 \%$ has symptoms), and 4 ( $>75 \%$ has symptoms). Finally, they were calculated using the following equation:

$\mathrm{CI}$ index $(\%)=[\Sigma(\mathrm{CI}$ levels $) \times($ number of fruits at this level $) /($ total number of fruits in the treatment $) \times 4] \times 100,(1)$

\subsubsection{Weight Loss}

Persimmon fruit samples were weighed at the beginning of the experiment and after each sampling time. The percentage of weight loss (\%) was calculated using the following equation:

Weight loss $(\%)=[($ fruits weight before storage - fruits weight after storage $) /$ fruits weight before storage $] \times 100$, 


\subsubsection{Fruit Firmness}

Fruit firmness was measured using a penetrometer (model FT 327) which was equipped with a $8 \mathrm{~mm}$ cylindrical head [27]. Data were represented in $\mathrm{kg} / \mathrm{cm}^{2}$. Three readings were obtained for each persimmon.

\subsubsection{Total Soluble Solids and Titrable Acidity}

Total soluble solids (TSS) were measured using a hand-held refractometer and the juice was prepared using a juicer (Atago Co., Ltd., Tokyo, Japan). The results were expressed as ${ }^{\circ}$ Brix. Titrable acidity (TA) was determined via the titration method with 0.1 normal sodium hydroxide $(\mathrm{NaOH})$ and was used to measure the TA of the fruit juice. The end point of the titration was when the $\mathrm{pH}$ of the extract reached 8.2, and the volume of $\mathrm{NaOH}$ consumed was recorded. The amount of TA in terms of the percentage of malic acid, the predominant persimmon acid substance, was calculated using the following formula [28]:

$$
\mathrm{TA}=(\mathrm{V} \times \mathrm{N} \times 68 / \mathrm{v} \times 1000) \times 100,
$$

where: TA, the amount of organic acid in the extract in milligrams per $100 \mathrm{~mL}$ of extract; $\mathrm{N}$, the normality of the consumption of $\mathrm{NaOH} ; \mathrm{V}$, the volume of the $\mathrm{NaOH}$ consumption; $\mathrm{v}$, the sample volume.

\subsubsection{MDA and $\mathrm{H}_{2} \mathrm{O}_{2}$ Content}

Malonaldehyde (MDA) content was measured according to the thiobarbituric acid (TBA) method [29]. MDA content was expressed on a fresh weight basis, $\mathrm{nmol} / \mathrm{g}$. The $\mathrm{H}_{2} \mathrm{O}_{2}$ content was assayed via the method described by Patterson et al. [30]. The content of $\mathrm{H}_{2} \mathrm{O}_{2}$ was expressed on a fresh weight basis in $\mathrm{nmol} / \mathrm{g}$, according to a standard curve.

\subsubsection{Soluble Tannin Content}

The soluble tannin content was measured using the Folin-Denis method described by Taira [31]. To do so, a fruit sample (1 g) was extracted with $10 \mathrm{~mL}$ of $80 \%$ methanol using a mortar. The soluble tannin content was assessed against standard tannic acid, expressed as $\mathrm{mg}$ of tannic acid equivalents per $\mathrm{kg}$ of the sample.

\subsubsection{Total Carotenoid Content}

Total carotenoid content was assayed by extracting $1 \mathrm{~g}$ of fruit tissue in $5 \mathrm{~mL}$ hexane and acetone (60:40) solution according to the method of Wang et al. [32]. The total carotenoid content was expressed on a fresh weight basis, $\mathrm{mg} / 100 \mathrm{~g}$.

\subsubsection{Polyphenol Oxidase Activity (PPO)}

Crude extract for PPO enzyme was performed by homogenizing $2 \mathrm{~g}$ of frozen flesh tissue with $12 \mathrm{~mL}$ of $50 \mathrm{mM}$ potassium phosphate buffer solution ( $\mathrm{pH}$ 6.8) containing $10 \%$ polyvinylpyrrolidone (PVP) and $0.5 \mathrm{M} \mathrm{KCl}$. Then, the homogenate was centrifuged at $14,000 \times g$ for $20 \mathrm{~min}$ at $4{ }^{\circ} \mathrm{C}$ to obtain supernatants for enzymatic assays. PPO enzymes activity was determined via the method described by Nguyen et al. [33]. The reaction mixture contained $1800 \mu \mathrm{L}$ potassium phosphate buffer and $500 \mu \mathrm{L}$ pyrocatechol solution $(0.5 \mathrm{M})$, and the supernatant $(700 \mu \mathrm{L})$ was recorded at $420 \mathrm{~nm}$ for $2 \mathrm{~min}$. PPO enzymes activity was expressed as $\mathrm{U} / \mathrm{mg}$ protein.

\subsubsection{Antioxidant Enzyme Activity}

To analyze the activity of superoxide dismutase (SOD), catalase (CAT), and ascorbate peroxidase (APX) enzymes, frozen persimmon fruit $(2 \mathrm{~g})$ was homogenized in phosphate buffer ( $50 \mathrm{mM}, \mathrm{pH} 7.8)$ containing EDTA $(0.2 \mathrm{mM})$ and PVP $(2 \%)$. The homogenate was centrifuged at $14,000 \times g$ for $20 \mathrm{~min}$ at $4{ }^{\circ} \mathrm{C}$ to obtain supernatants for enzymatic assays. The activities of SOD, CAT, and APX were determined based on the method reported by Zhang et al. [34]. One unit of CAT activity was defined as a 0.01 decrease of absorbance at $240 \mathrm{~nm}$ 
per min. One unit of APX activity was defined as a decrease in absorbance at $290 \mathrm{~nm}$ of 0.01 per min. One unit of SOD activity is defined as the enzyme that causes a $50 \%$ inhibition of nitro blue tetrazolium reduction at $560 \mathrm{~nm}$ under assay conditions. Antioxidant enzymes (CAT, SOD, and APX) activities were expressed as U/mg protein. Protein content in the enzyme extracts was assayed based on the method reported by Bradford [35] with bovine serum albumin (BSA) as standard.

\subsubsection{Antioxidant Capacity}

For antioxidant capacity determination, one-gram fruit samples were extracted with $0.1 \% \mathrm{HCl}$ acidified $80 \%$ methanol $(v / v)(8 \mathrm{~mL})$ and then centrifuged $(10,000 \times g, 20 \mathrm{~min}$, $4{ }^{\circ} \mathrm{C}$ ). Antioxidant capacity was assayed using the DPPH radical-scavenging method according to Dehghan and Khoshkam [36]. The DPPH scavenging activity (\%) was expressed as the percentage of inhibition of DPPH radical.

$$
\% \text { Inhibition of DPPH } \bullet=(\text { Abs control }- \text { Abs sample }) / \text { Abs control } \times 100 \text {, }
$$

\subsection{Statistical Analysis}

The experiments were performed using a completely randomized design. Normal distribution and variance homogeneity had been previously tested (Shapiro-Wilk). To determine the effects of chitosan, phenylalanine, and Cs-Phe NPs treatment and storage time IBM SPSS (version 22) statistical software was used. Differences between means were assessed via Duncan's test, with differences considered significant at $P \leq 0.05$.

\section{Results and Discussion}

\subsection{Synthesis and Characterization of Cs-Phe NPs}

Spectrum FT-IR was used to study the chemical structure of Cs, Phe, TPP, and Phe-Cs NPs (Figure 1a). In the chitosan spectrum, signals at 3448 and $1601 \mathrm{~cm}^{-1}$ are related to stretching vibration $-\mathrm{OH}$ and $-\mathrm{NH}_{2}$, respectively, and the signal in $1076 \mathrm{~cm}^{-1}$ is attributed to stretching vibration C-O-C. Data FT-IR were used to identify the Phe in the nanocomposite [37]. In the Phe spectrum, the signal at $1563 \mathrm{~cm}^{-1}$ is related to the stretching vibrations of the carbonyl group. The absorption band at $3440 \mathrm{~cm}^{-1}$ shows the $-\mathrm{COOH}$ structure in this material. In addition, the peak in areas 2963 and $1625 \mathrm{~cm}^{-1}$ is related to $\mathrm{C}-\mathrm{H}$ and $\mathrm{C}=\mathrm{C}$, respectively, which indicates the presence of a benzene ring [38]. In the TPP spectrum, the signal at $885 \mathrm{~cm}^{-1}$ is attributed to the stretching vibrations of the $\mathrm{P}-\mathrm{O}-\mathrm{P}$ bond. Peaks 1175 and $1231 \mathrm{~cm}^{-1}$ are also related to the stretching vibrations of the $\mathrm{P}=\mathrm{O}$ and $\mathrm{P}-\mathrm{O}$ bonds, respectively. The bending vibrations of $-\mathrm{NH}_{2}$ have shifted from $1657 \mathrm{~cm}^{-1}$ to $1630 \mathrm{~cm}^{-1}$, and the new peak created in $1583 \mathrm{~cm}^{-1}$ refers to the interaction between $-\mathrm{NH}_{3}{ }^{+}$in Cs and TPP in the nanocomposite, which indicates the loading of Phe in the nanocomposite.

$\mathrm{X}$-ray diffraction was used to describe the formation of nanocomposites (Figure 1b). Pattern XRD for Cs shows the nature of the semi-crystalline at a slightly wider peak at $2 \theta=20$ [37]. After interacting with TPP, the Cs peak appeared with less intensity in the nanocomposite in the new peaks $2 \theta=18$ and 22, which indicates ionic interactions in the crystal lattice. The surface morphology and transmission electron microscopy images of the prepared nanocomposite were determined using SEM and TEM methods (Figure 1c,d). The results showed that the surface of the nanocomposite contained spherical nanoparticles and no porosity was observed. Transmission electron microscopy images also estimated the nanoparticles to be $100 \mathrm{~nm}$ in size. 
(a)

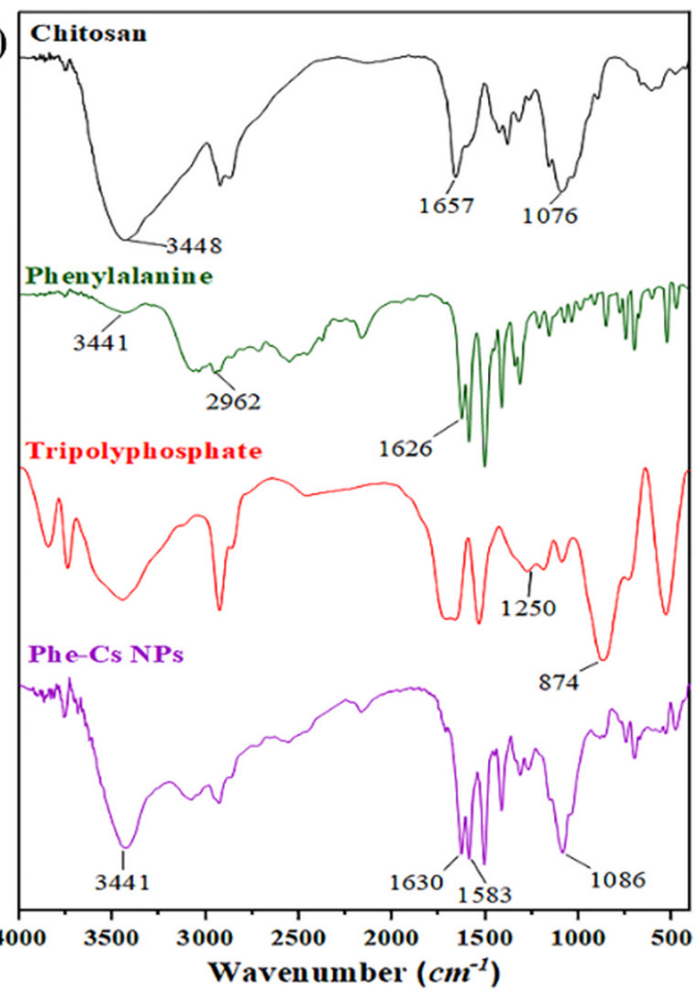

(c)

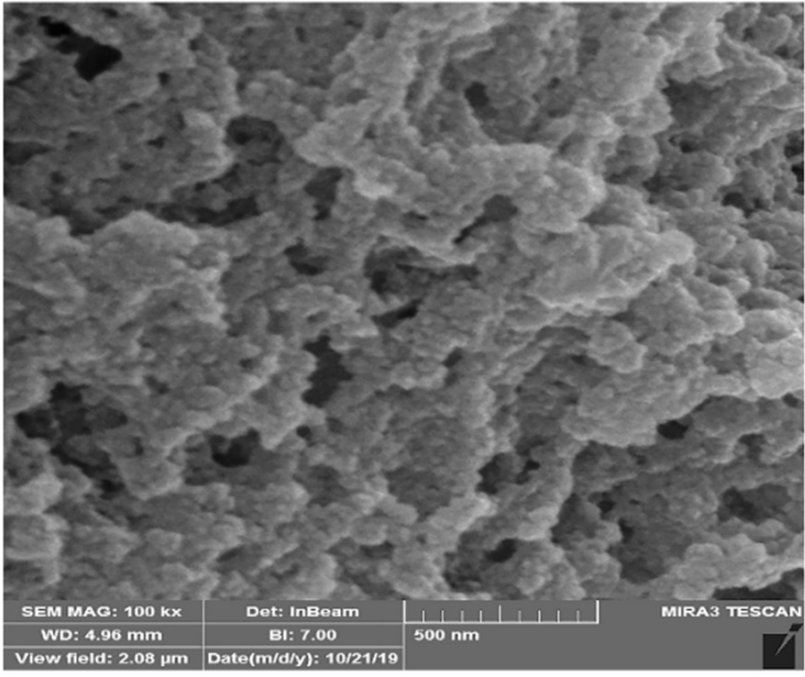

(b)

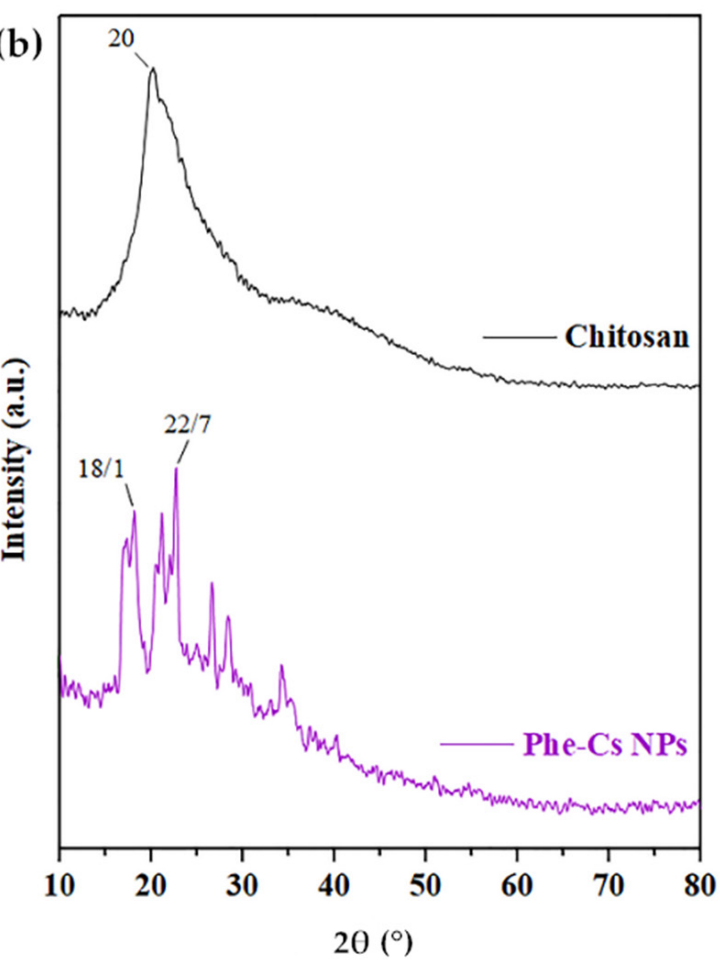

(d)

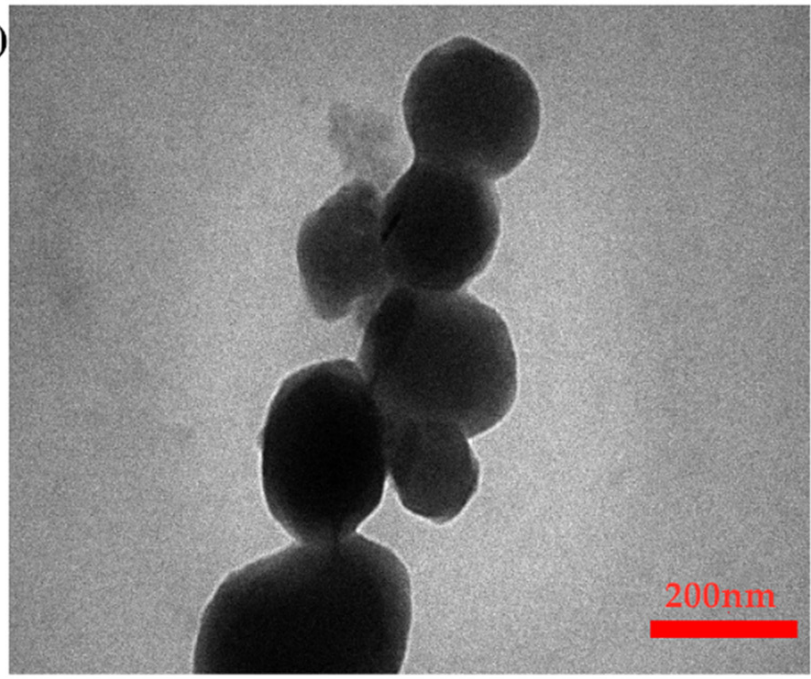

Figure 1. FT-IR (a), XRD (b) SEM (c), and TEM (d) analysis of starting materials and chitosan-phenylalanine nanoparticles (Cs-Phe NPs).

\subsection{Fruit Chilling Index}

The results showed that chilling damage increased during storage in control and treated fruits. The fruit treated with Cs-Phe NPs 2.5 and $5.0 \mathrm{mM}$ showed significantly reduced chilling damage compared to control and other treatments (Figure 2). 
$\square$ Control $\mathbf{s}$ Cs $1 \%(w / v) \square$ Phe $5 \mathrm{mM}$ ノCs-Phe NPs $2.5 \mathrm{mM} \square$ Cs-Phe NPs $5 \mathrm{mM}$

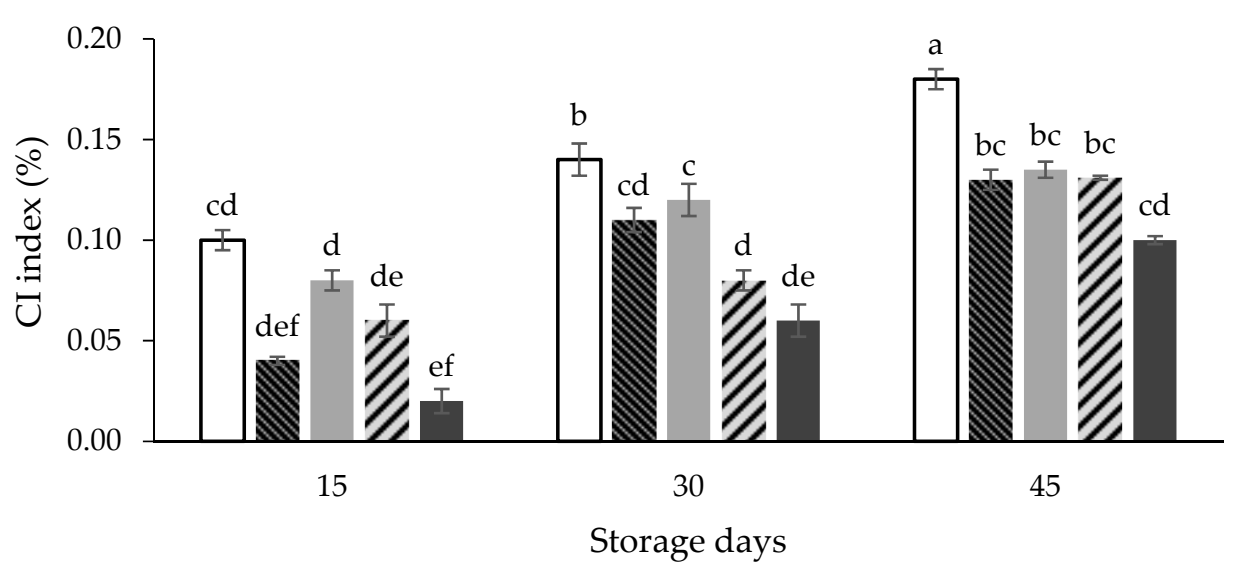

Figure 2. Effects of chitosan, phenylalanine, and chitosan-coated phenylalanine nanoparticles treatments on the chilling index of persimmon fruit during storage at $4{ }^{\circ} \mathrm{C}$ for 15,30 , and 45 days. Each value represents the mean \pm standard errors of three replications. Different letters indicate statistical differences using Duncan's multiple range tests at $P<0.05$ level.

The results showed that with increasing concentration of Cs-Phe NPs treatment, the percentage of chilling injury and jelly became less in persimmon fruit during 45 days of storage. The highest jelling symptoms were observed in control fruits and the lowest chilling damage in Cs-Phe NPs $(5 \mathrm{mM})$ treatment at the end of storage. There was no significant difference between all treatments for 15 days of storage. In addition, at 30 days, the highest and lowest chilling index was absorbed in control and $5 \mathrm{mM}$ Cs-Phe NPs treatment, respectively. Cs-Phe NPs treatment significantly increased the tolerance of persimmon fruits to chilling damage in all measured days (Figure 2). Chilling injury revealed by peel browning and texture jelling appeared in persimmon fruit during cold storage [39]. In this study softening and jelling texture were observed in fruit during storage. Persimmon fruit is highly sensitive to chilling injury, and storage at temperatures below $1{ }^{\circ} \mathrm{C}$ can cause chilling damage [39]. Chilling injury has been associated with decreased resistance and permeability of cell membranes by increasing levels of ROS, mainly hydrogen peroxides $\left(\mathrm{H}_{2} \mathrm{O}_{2}\right)$ and superoxide $\left(\mathrm{O}^{2-}\right)$. It seems that the application of Cs-Phe NPs could increase fruit tolerances to chilling injury by inducing the defense responses which could reduce ROS and preserving the cell membrane via the formation of phenolic and antioxidant compounds [40]. Zhu et al. [41] showed that fruit coating using edible polymer such as chitosan has improved inhibition of ROS production and prevented chilling damage in fruit, which is in agreement with our findings. Some recent studies reported that coating with Cs prevented the increasing of chilling injury in fruit. In this regard, banana treated with chitosan nanoparticles showed slower skin browning and gelling compared to untreated banana at 11 days of storage [23]. Nanocellulose/chitosan composite treatment also decreased chilling symptoms on cucumber by increasing antioxidant enzymes activity [42], which is in agreement with our results.

\subsection{Weight Loss}

The weight loss of all treatment and control fruits increased during storage. The percentage of weight loss was affected by Cs, Phe, and Cs-Phe NPs treatments. The weight loss rate of fruit coated with Cs-Phe NPs in both tested concentrations was much lower than with other treatments and control. In control, the fruits' weight was lower than other treatments during storage. All treated fruits preserved fruit weight loss compared to control fruit during 45 days of cold storage. There was no significant difference between Cs and Phe treatment during storage time. The lowest weight loss was observed in the treatment of $5 \mathrm{mM}$ Cs-Phe NPs during storage (Table 1). Loss of weight in persimmons caused withering, 
softening, and decreased quality of the fruit [39]. During storage, fruit weight loss is significantly contributed to by increased respiration rate and evaporation and increases the consumption of fruit nutrients [43]. Chitosan provides uniform and stiff binding to surfaces of persimmon fruits that prevents increased respiration and delays transpiration rates [44]. Some recent studies reported that fruit coated with $\mathrm{Cs}$ were prevented from reducing in weight, water vapor transmission rate and $\mathrm{O}_{2} / \mathrm{CO}_{2}$ by increasing surface and interface roughness and due to a smaller pore size, thus preventing the percentage of weight loss [41]. Menna et al. [25] reported Cu-chitosan nano significantly prevented weight loss in tomato during 21 days storage, which is in accordance with our study. Furthermore, chitosan/nano- $\mathrm{TiO}_{2}$ composite treatment could prevent weight loss in mango fruits [27].

Table 1. Effects of chitosan (Cs), phenylalanine (Phe), and chitosan-coated phenylalanine nanoparticles (Cs-Phe NPs) treatments on the weight loss, firmness, TA, and TSS of persimmon fruit during storage at $4{ }^{\circ} \mathrm{C}$ for 15,30 , and 45 days.

\begin{tabular}{|c|c|c|c|c|c|}
\hline Storage Days & Treatment & Weight Loss (\%) & Firmness $\left(\mathrm{kg} / \mathrm{cm}^{2}\right)$ & TA (\%) & TSS (\%) \\
\hline \multirow{5}{*}{15} & Control & $3.98 \pm 0.2^{b c}$ & $4.01 \pm 0.4^{\mathrm{cd}}$ & $0.38 \pm 0.06^{\mathrm{cd}}$ & $18.36 \pm 0.8^{b c}$ \\
\hline & Cs $1 \%(w / v)$ & $3.47 \pm 0.3^{\mathrm{cd}}$ & $4.45 \pm 0.5^{b c}$ & $0.44 \pm 0.02^{b}$ & $18.3 \pm 0.6^{b c}$ \\
\hline & Phe $5 \mathrm{mM}$ & $3.44 \pm 0.06^{\mathrm{cd}}$ & $4.3 \pm 0.1^{\mathrm{bcd}}$ & $0.45 \pm 0.01^{b}$ & $17.66 \pm 0.8^{b c d}$ \\
\hline & Cs-Phe NPs $2.5 \mathrm{mM}$ & $2.8 \pm 0.3^{\mathrm{de}}$ & $5.1 \pm 0.08^{a}$ & $0.46 \pm 0.01^{\mathrm{ab}}$ & $17 \pm 1.2^{\mathrm{cd}}$ \\
\hline & Cs-Phe NPs 5 mM & $2.3 \pm 0.04^{\mathrm{e}}$ & $5.2 \pm 0.1^{\mathrm{a}}$ & $0.48 \pm 0.04^{\mathrm{a}}$ & $16.66 \pm 0.5^{\mathrm{d}}$ \\
\hline \multirow{5}{*}{30} & Control & $4.6 \pm 0.5^{\mathrm{ab}}$ & $2.1 \pm 0.8^{f}$ & $0.35 \pm 0.03^{\text {cde }}$ & $20.93 \pm 0.6^{b}$ \\
\hline & Cs $1 \%(w / v)$ & $3.7 \pm 0.1^{\mathrm{c}}$ & $3.7 \pm 0.2^{\mathrm{de}}$ & $0.44 \pm 0.02^{\mathrm{b}}$ & $20.45 \pm 0.2^{b}$ \\
\hline & Phe $5 \mathrm{mM}$ & $3.8 \pm 0.02^{c}$ & $3.9 \pm 0.1^{\text {cde }}$ & $0.41 \pm 0.01^{\mathrm{c}}$ & $20.35 \pm 0.5^{b}$ \\
\hline & Cs-Phe NPs2.5 mM & $3.2 \pm 0.1^{\mathrm{d}}$ & $4.46 \pm 0.06^{b c}$ & $0.43 \pm 0.03^{b c}$ & $18.98 \pm 1.3^{b c}$ \\
\hline & Cs-Phe NPs 5 mM & $2.9 \pm 0.2^{\text {de }}$ & $4.5 \pm 0.04^{b c}$ & $0.46 \pm 0.01^{\mathrm{ab}}$ & $20.2 \pm 0.5^{b}$ \\
\hline \multirow{5}{*}{45} & Control & $4.8 \pm 0.8^{a}$ & $0.4 \pm 1.1^{\mathrm{g}}$ & $0.25 \pm 0.05^{\mathrm{e}}$ & $22.3 \pm 0.2^{a}$ \\
\hline & $\operatorname{Cs} 1 \%(w / v)$ & $4.1 \pm 0.2^{b}$ & $3.3 \pm 0.3^{\text {ef }}$ & $0.32 \pm 0.03^{\mathrm{de}}$ & $21.12 \pm 1.1^{\mathrm{ab}}$ \\
\hline & Phe $5 \mathrm{mM}$ & $4.3 \pm 0.02^{b}$ & $3.2 \pm 0.2$ ef & $0.31 \pm 0.1^{\mathrm{de}}$ & $21.89 \pm 0.5^{\mathrm{ab}}$ \\
\hline & Cs-Phe NPs2.5 mM & $4.1 \pm 0.1^{b}$ & $3.5 \pm 0.2^{\mathrm{e}}$ & $0.36 \pm 0.02^{\mathrm{cd}}$ & $19.5 \pm 0.4^{\mathrm{bc}}$ \\
\hline & Cs-Phe NPs 5 mM & $3.2 \pm 0.1$ de & $4.01 \pm 0.05^{\mathrm{cd}}$ & $0.33 \pm 0.06^{\mathrm{de}}$ & $21.55 \pm 1.2^{\mathrm{ab}}$ \\
\hline
\end{tabular}

Each value represents the mean \pm standard errors of three replications. Different letters indicate statistical differences using Duncan's multiple range tests at $P<0.05$ level.

\subsection{Fruit Firmness}

Our results showed that Cs-Phe NPs treatment had a significant effect on the protection of fruit tissue firmness. Fruit firmness of all fruit increased over time from 15 to 45 days of storage. On days 30 and 45 of the storage period, the highest firmness was observed in the control fruit. The fruit coating with Cs-Phe NPs $5 \mathrm{mM}$ was more effective than other treatments in the prevention of decreased fruit firmness compared with control and other treatments. The highest firmness was obtained at Cs-Phe NPs $5 \mathrm{mM}$ (Table 1). Cs-Phe NPs treatments greatly maintained fruit firmness. The lowest fruit firmness $\left(0.4 \mathrm{~kg} / \mathrm{cm}^{2}\right)$ was obtained in the control at 45 days of storage. No significant difference was observed between treatments of phenylalanine, chitosan, and $2.5 \mathrm{mM}$ Cs-Phe NPs at 45 days after storage. The protection of flesh stiffness is a main factor for increasing the quality and increased marketing of persimmon fruit [45]. Decreasing of firmness was associated with increased respiration and cell wall destroyer enzyme activities that cause breakdown of structural polysaccharides, especially hemicellulose and pectins in the cell wall [46]. Cs-Phe NPs treatment formed a thin layer on the surface of the fruit and modified the exchange of gas $\mathrm{O}_{2}$ and $\mathrm{CO}_{2}$ in the fruit, directly affecting the fruit respiration rate and further delaying the decrease in firmness [41]. Meena et al. [25] reported that fruit coated with Cs prevented the reducing of firmness; for example, cu-chitosan nano-net maintained firmness in tomato fruit for 15 days with the entire surface of the fruit covered and controlled moisture loss and gas exchanges and decreased respiration rate. Cs-Phe NPs treatment in this study significantly prevented decrease in the firmness of persimmon fruits, which is consistent with the results reported by Meena et al. [25]. The keeping of stiffness of the coated fruits 
with chitosan/titanium dioxide nanocomposite due to increased antioxidant enzymes has been reported during storage in mango fruit [27].

\subsection{TSS and TA}

TSS values gradually increased from the 15th to the 45th day of storage (Table 1). Cs-Phe NPs treatments delayed the increasing of TSS in persimmon fruits during storage. The TSS value of control fruit increased during cold storage; however, fruits treated with 2.5 and $5 \mathrm{mM}$ Cs-Phe NPs exhibited a higher TSS value than control fruit during storage. Furthermore, there was no significant difference between all treatments and control fruits for 30 days of storage time (Table 1). The amount of total soluble solids in persimmon depends on the soluble tannins too. During the ripening process, due to respiration increasing the production and activity of enzymes which break down the cell wall, breakdown of polymeric carbohydrates in the cell wall occurred and finally caused an increase of TSS in fruits [47]. Application of nano- $\mathrm{SiO}_{2} /$ chitosan caused an increase of TSS in tomato fruit compared with control [41]. Meena et al. [25] reported that Cu-chitosan nano-net treatment significantly prevented the increase of TSS by decreasing respiration and metabolic activities, as a result decreasing sugars in tomato. However, in another study chitosan-silica nanocomposites had no effect on TSS content [48]. Chitosan/nano- $\mathrm{TiO}_{2}$ composite prevented the increasing of TSS in mango fruit by regulating gas exchange and transpiration [27].

Storage time and treatment had a significant effect on TA in persimmon during storage (Table 1). The highest amount of TA was observed in Cs-Phe-NPs-treated fruits, and the lowest amount of TA was observed in control fruits after 45 days of storage. Cs-Phe NPs treatments significantly maintain the TA content of fruits compared to the chitosan and phenylalanine treatment alone. The TA content is directly related to the amount of organic acids in the fruit, which is converted to sugar during respiration due to metabolic changes and decreases during storage [49]. Chitosan of Cu-chitosan NPs prevented decreasing of TA during storage in tomato due to declined respiration via nano-net, and the low respiration rate finally prevents the consumption of organic acids [25]. Chitosan-silica nanocomposites did not affect TA content in grapes [48]. In addition, chitosan/cellulose nano fibril nanocomposite did not affect strawberries during storage [24].

\section{6. $\mathrm{MDA}$ and $\mathrm{H}_{2} \mathrm{O}_{2}$}

The $\mathrm{H}_{2} \mathrm{O}_{2}$ accumulation in all fruit increased over time, while $\mathrm{H}_{2} \mathrm{O}_{2}$ accumulation in fruit treated with 2.5 and $5 \mathrm{mM}$ of Cs-Phe NPs was significantly lower than that of control fruit. An overview of the results during the storage period should be given $-5 \mathrm{mM} \mathrm{NPs}$ significantly reduced MDA on the 15th day compared to control; Cs and $2.5 \mathrm{mM} \mathrm{NPs} \mathrm{on}$ the 30th day compared to control, although NPs treatments resulted in significantly lower values compared to Cs; and Cs and both NPs treatments on the 45th day. The highest and lowest levels of MDA were observed in control $(6.2 \mathrm{nmol} / \mathrm{g} \mathrm{FW})$ and Cs-Phe NPs $2.5 \mathrm{mM}$ (4.4 nmol/g FW), respectively, at the end of storage (Figure 3). Cs-Phe NPs significantly prevented increase of MDA during 45 days of storage compared to control and other treatments. No significant difference was observed between phenylalanine and chitosan treatments. Cold storage with production of reactive oxygen species caused oxidative stress in plants [50]. Reactive oxygen species such as superoxide radicals, hydrogen peroxide, and hydroxyl radicals can directly damage membranes and increase peroxidation of membrane lipids [51]. MDA was produced from the lipid peroxidation membrane and showed how many cells experienced senescence [52]. Cs-Phe NPs treatment could improve the membrane integrity and decreased MDA during storage. Chitosan/nano-silica treatment could increase antioxidant enzymes activity, remove ROS, and prevented increase of MDA content in treated loquat [53]. Xing et al. [27] reported that MDA content in mango fruit treated with chitosan/nano- $\mathrm{TiO}_{2}$ composite was lower than fruit treated with chitosan treatment and control. 
$\square$ Control $\mathbf{N}$ Cs $1 \%(\mathrm{w} / \mathrm{v}) \square$ Phe $5 \mathrm{mM}$ ノCs-Phe NPs $2.5 \mathrm{mM} \square$ Cs-Phe NPs $5 \mathrm{mM}$

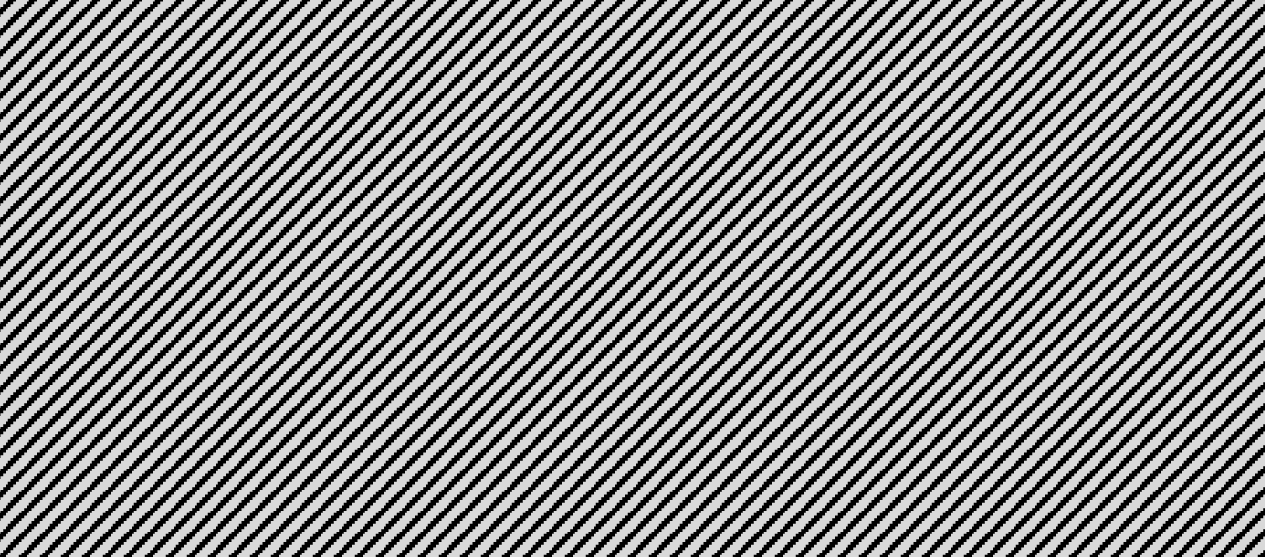

Figure 3. Effects of chitosan, phenylalanine, and chitosan-coated phenylalanine nanoparticles treatments on the MDA content of persimmon fruit during storage at $4{ }^{\circ} \mathrm{C}$ for 15,30 , and 45 days. Each value represents the mean \pm standard errors of three replications. Different letters indicate statistical differences using Duncan's multiple range tests at $P<0.05$ level.

The $\mathrm{H}_{2} \mathrm{O}_{2}$ content at harvest time increased over 30 days then decreased at the end of storage. All treatments effectively prevented the increase of $\mathrm{H}_{2} \mathrm{O}_{2}$ content as compared with control fruits. However, the $\mathrm{H}_{2} \mathrm{O}_{2}$ content was significantly lower in Cs-Phe-NPstreated persimmon fruits than chitosan- and phenylalanine-treated fruits during 45 days of storage. The highest $\mathrm{H}_{2} \mathrm{O}_{2}$ value was observed in control fruits $(24.3 \mathrm{nmol} / \mathrm{g} \mathrm{FW})$ at the end of storage (Figure 4).



Figure 4. Effects of chitosan, phenylalanine, and chitosan-coated phenylalanine nanoparticles treatments on the $\mathrm{H}_{2} \mathrm{O}_{2}$ content of persimmon fruit during storage at $4{ }^{\circ} \mathrm{C}$ for 15,30 , and 45 days. Each value represents the mean \pm standard errors of three replications. Different letters indicate statistical differences using Duncan's multiple range tests at $P<0.05$ level.

Reactive oxygen species such as $\mathrm{H}_{2} \mathrm{O}_{2}$ increased in fruits and vegetables during storage time via oxidative stress such as cold stress [54]. Nano carrier coatings could delay postharvest senescence by protecting the cellular membrane structures and removing ROS such as $\mathrm{H}_{2} \mathrm{O}_{2}$ [55]. Attia et al. [56] reported that eggplant treated with chitosan and EDTA-conjugated graphene oxide retained lower levels of $\mathrm{H}_{2} \mathrm{O}_{2}$ as compared to control fruits. In addition, chitosan-selenium nanoparticles significantly decreased $\mathrm{H}_{2} \mathrm{O}_{2}$ in melon by removing ROS and increasing antioxidant contents [57]. 


\subsection{Soluble Tannin and Total Carotenoid}

The amount of soluble tannin at harvest time was $5848 \mathrm{mg} / \mathrm{kg} \mathrm{FW}$ in control fruits, which decreased during storage in treated and control fruits. The Cs-Phe NPs treatments significantly preserved the soluble tannin and prevented its reduction during cold storage. At the end of the storage period, Cs-Phe-NPs-treated fruits enhanced the soluble tannins in comparison with solely Cs and Phe treatments. The highest amount of soluble tannins at the end of storage was related to both tested concentrations of Cs-Phe NPs. Furthermore, Cs-Phe NPs treatment was better than solely Phe and Cs treatments and could prevent the reduction of soluble tannins (Figure 5).

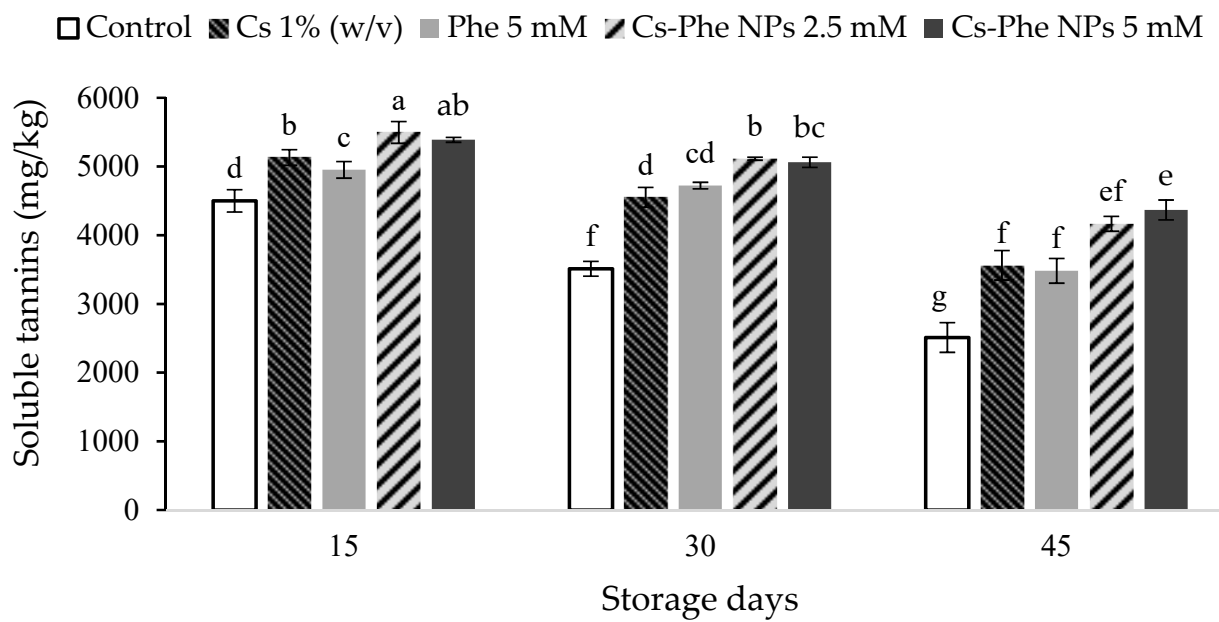

Figure 5. Effects of chitosan, phenylalanine, and chitosan-coated phenylalanine nanoparticles treatments on the soluble tannins content of persimmon fruit during storage at $4{ }^{\circ} \mathrm{C}$ for 15,30 , and 45 days. Each value represents the mean \pm standard errors of three replications. Different letters indicate statistical differences using Duncan's multiple range tests at $P<0.05$ level.

Persimmon fruit is an astringent type and the content of its soluble tannin at harvest time is higher than $1000 \mathrm{ppm}$ [58]. Tannin is a relatively unstable compound that decreases with increasing storage period. The amount of soluble tannin reached one of the main indicators related to the quality of persimmon fruit. The amount of soluble tannin decreased continuously during storage due to the formation of a complex between the pectin released from the cell wall and the tannin. The soluble tannin combines with the released pectin and precipitates and becomes insoluble during postharvest [31]. Chitosan coating could maintain cell wall firmness and prevent cell wall demolition, then it could prevent the cell wall from releasing soluble pectin, thereby retarding the decrease of tannin content [59].

According to our results, the highest amount of total carotenoids was observed in the control $(0.93 \mathrm{mg} / 100 \mathrm{~g} \mathrm{FW})$ and phenylalanine treatment $(0.94 \mathrm{mg} / 100 \mathrm{~g} \mathrm{FW})$ at the end of the storage (Figure 6). Cs-Phe NPs treatment significantly prevented the increasing of carotenoid content at the 45th day of cold storage. Carotenoids are lipid-soluble pigments, which play an antioxidant role in postharvest oxidative stress [60]. Zhou et al. [61] reported that persimmon fruit's color mainly resulted from the carotenoids, and $\beta$-cryptoxanthin and zeaxanthin was the most abundant in persimmon fruits. There are various reports of the effect of nanoparticles on carotenoids. Coatings of chitosan with Byrsonima crassifolia extract prevented the increasing of total carotenoid in pepper [62]. On the other hand, chitosanEpigallocatechin-3-gallate (EGCG) conjugates prevented a decrease of carotenoid due to the selective permeability of chitosan coating [63]. The result of this study is consistent with a previous study of graphene oxide and zinc oxide nanoparticles application on carrot whereby the nanoparticles decreased carotenoid in carrot [64]. 
$\square$ Control $\mathbf{N C s} 1 \%(\mathrm{w} / \mathrm{v}) \square$ Phe $5 \mathrm{mM}$ ノCs-Phe NPs $2.5 \mathrm{mM} \square$ Cs-Phe NPs $5 \mathrm{mM}$

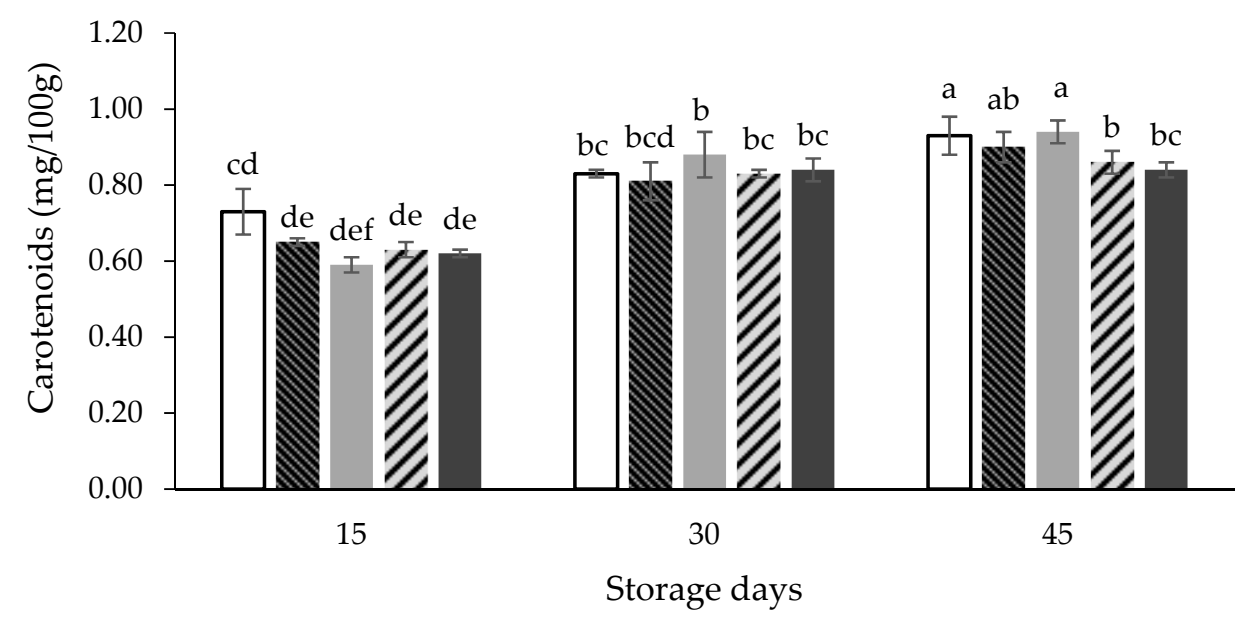

Figure 6. Effects of chitosan, phenylalanine, and chitosan-coated phenylalanine nanoparticles treatments on the carotenoids content of persimmon fruit during storage at $4{ }^{\circ} \mathrm{C}$ for 15,30 , and 45 days. Each value represents the mean \pm standard errors of three replications. Different letters indicate statistical differences using Duncan's multiple range tests at $P<0.05$ level.

\subsection{Polyphenol Oxidase Activity (PPO)}

The Cs-Phe NPs treatments has the greatest effect on reducing the activity of polyphenol oxidase enzyme. Application of nanocomposite treatments significantly decreased PPO activity compared to control as well as to treatments with chitosan and phenylalanine alone. Control fruits had the highest polyphenol oxidase activity (15.3 U/g FW) at the end of storage (Figure 7).

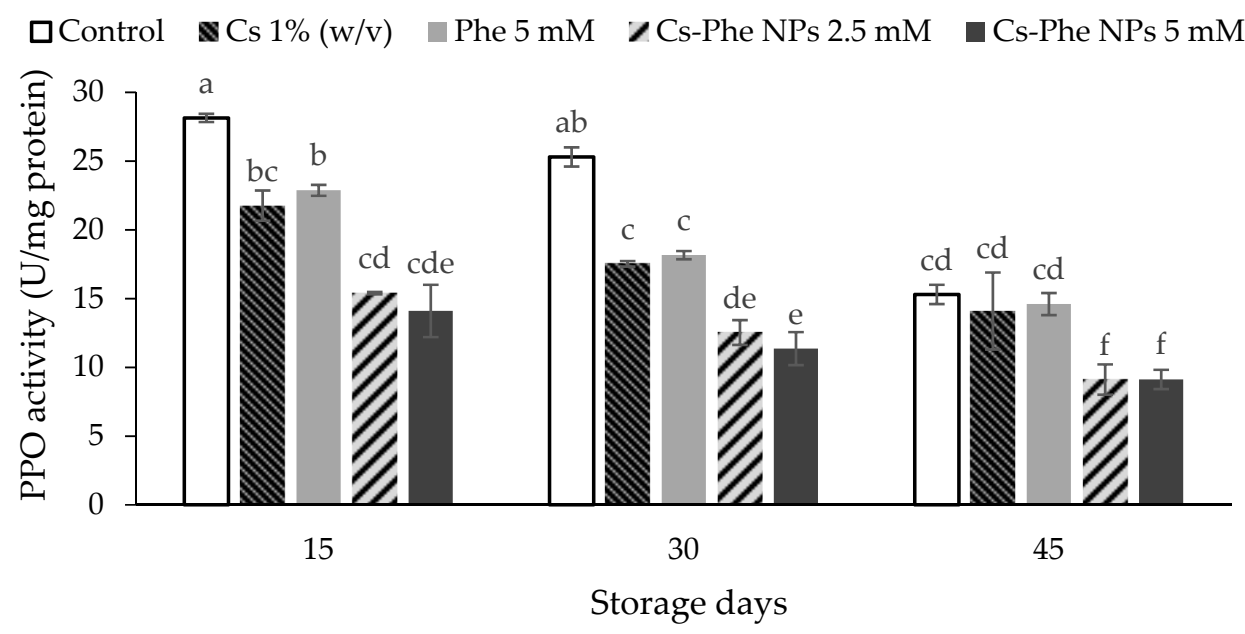

Figure 7. Effects of chitosan, phenylalanine, and chitosan-coated phenylalanine nanoparticles treatments on the PPO activity of persimmon fruit during storage at $4{ }^{\circ} \mathrm{C}$ for 15,30 , and 45 days. Each value represents the mean \pm standard errors of three replications. Different letters indicate statistical differences using Duncan's multiple range tests at $P<0.05$ level.

Polyphenol oxidase is one of the antioxidant enzymes that has a key role in the enzymatic browning of most fruits and vegetables in postharvest, causing damage to the integrity of the membrane during fruit senescence [65]. PPO may accept monophenols and/or o-diphenols as substrates [66]. In most plants, polyphenol oxidase bonds strongly with the chloroplast membrane, and the substrates of these PPO reactions are located in the vacuoles of plants when the cells' membrane is damaged due to aging or stress conditions (increase ROS) during postharvest; PPO activates and initiates a chain of browning 
reactions $[67,68]$. Sathiyabama et al. [69] reported that chitosan nanoparticles loaded with thiamine could prevent increasing of PPO activity by preserving cell membrane stability and activation of antioxidant enzymes and genes related to ROS scavengers in treated fruit. Tomato treated with nano-SiO$/$ / chitosan treatment showed the lowest amount of PPO activity compared to chitosan treatment alone and other treatments [41].

\subsection{CAT, SOD, and APX Activity}

No significant difference $(P<0.01)$ was observed between $C$ s and Phe treatment in all storage times for CAT, SOD, and APX enzyme activities. In this study, fruits treated with nanocomposite had higher antioxidant enzymes activity than control fruit during cold storage. However, compared to the control fruit, the effect of $5 \mathrm{mM}$ of Cs-Phe NPs treatment on ascorbic acid accumulation varied according to the time of the study. The amount of CAT activity was decreased during storage time. The highest level of catalase activity was observed in fruits treated with Cs-Phe NPs. During cold storage, application of Cs-Phe NPs ( $5 \mathrm{mM})$ significantly inhibited the decrease of CAT enzyme activity. The lowest CAT activity was observed in control fruits at end of storage. Cs-Phe NPs treatments significantly protected CAT activity compared to control and other treated fruits (Figure 8a). During cold storage, the activity of SOD increased initially and then decreased until the end of storage. Both concentrations of Cs-Phe NPs significantly prevented the decreasing of SOD activity during storage. The highest amount of SOD activity was observed in the Cs-Phe NPs $5 \mathrm{mM}$ treatments at the end of cold storage (Figure 8b). A study of the trend of APX activity during cold storage showed that APX activity in all fruit decreased significantly over time. Although APX activities in all treated persimmon fruits and control fruits decreased after 45 days, treated samples had higher APX activity compared with control fruits. Cs-Phe NPs significantly prevented decrease of APX activity during storage (Figure 8c). CAT is one of the main antioxidant enzymes that delays or inhibits oxidative processes via free radicals and neutralizes oxygen free radicals and transfers a hydrogen atom to it, thereby preventing oxidative processes [70]. In this study the CAT, SOD, and APX activities of persimmon treated with Cs-Phe NPs were found to be higher than with other treatments. These data indicate that the beneficial effects of Cs-Phe NPs on increasing of antioxidant content is possibly associated with the lower rate of $\mathrm{O}_{2} / \mathrm{CO}_{2}$ transmission coefficient and reactive oxygen species (ROS) deletion [69]. Low temperature stress and ripening causes the production of reactive oxygen radicals such as superoxide radicals. These radicals act as signals that trigger SOD activation. SOD is a secondary signal and activates antioxidant enzymes [71]. SOD plays a leading role in the antioxidant defense mechanism. Superoxide radicals are converted to hydrogen peroxide via SOD activity, and hydrogen peroxide is converted to hydrogen peroxide via catalase and superoxide dismutase activity [72]. Stimulation of SOD activity stimulates ascorbate peroxidase activity. The increased activity of SOD, CAT, and APX leads to a reduction of ROS accumulation and decrease of CI symptoms in fruits [73]. The balance between the production and decomposition of $\mathrm{H}_{2} \mathrm{O}_{2}$ in the antioxidant system reduces the damage caused by low oxidative stresses and temperatures [74]. Cu-chitosan nanoparticles increased antioxidant enzymes activity via ROS removal [75]. Chitosan/nano- $\mathrm{TiO}_{2}$ composite treatment significantly prevented decrease of antioxidant enzyme in mango fruit during cold storage [27]. 


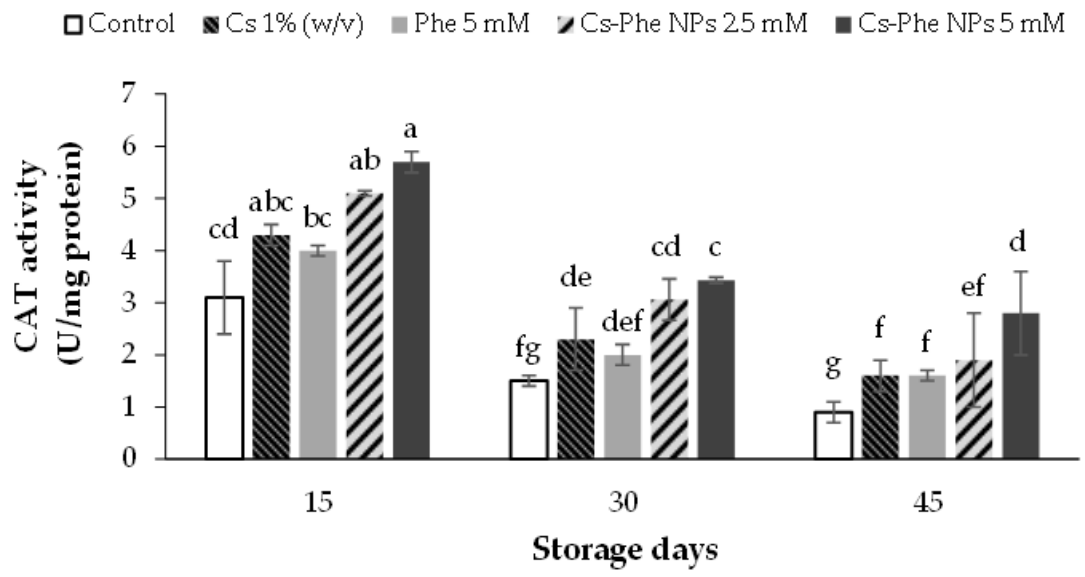

(a)

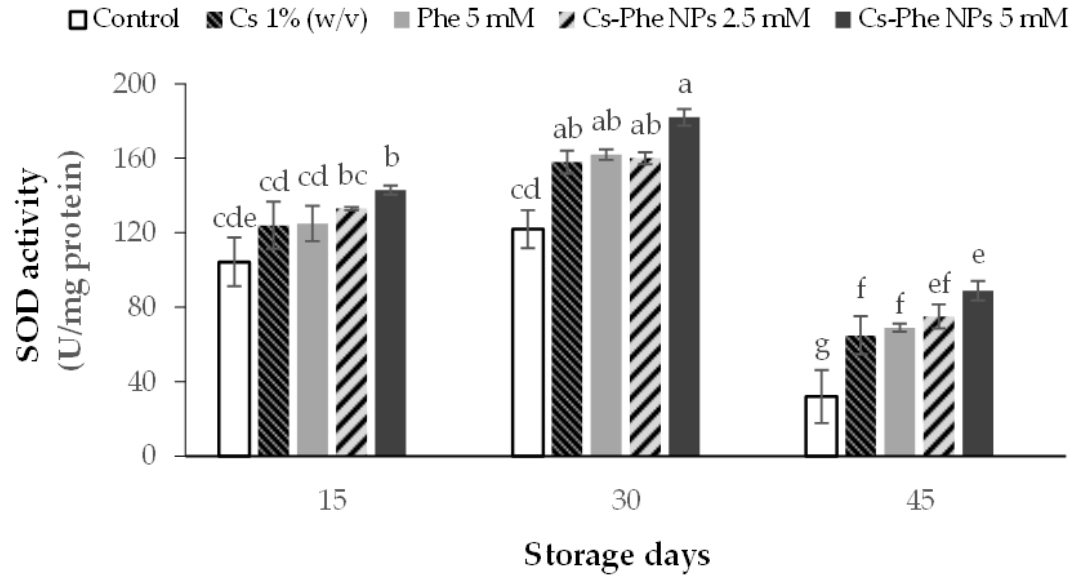

(b)

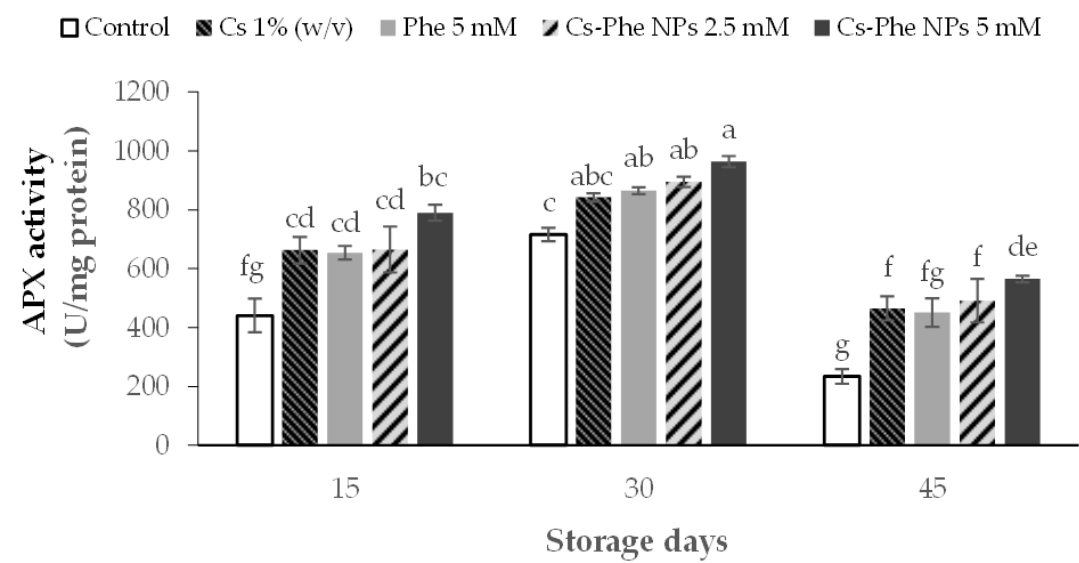

(c)

Figure 8. Effects of chitosan, phenylalanine, and chitosan-coated phenylalanine nanoparticles treatments on the CAT (a), SOD (b), and APX (c) activities of persimmon fruit during storage at $4{ }^{\circ} \mathrm{C}$ for 15,30 , and 45 days. Each value represents the mean \pm standard errors of three replications. Different letters indicate statistical differences using Duncan's multiple range tests at $P<0.05$ level.

\subsection{Antioxidant Capacity}

The present results showed that Cs-Phe NPs coating resulted in the highest DPPH radical scavenging activity as compared to $\mathrm{Cs}$ and control at 30 days of cold storage (Figure 9). Fruit coating using Cs-Phe NPs significantly delayed the total antioxidant 
decrease of the persimmon fruit, more effectively after 45 days of storage. The lowest DPPH radical scavenging activity was observed in control fruits $(39.2 \%)$ and the highest antioxidant was observed in Cs-Phe NPs $(2.5 \mathrm{mM})$ treatments at the end of cold storage. Cs-Phe NPs significantly prevented the decreasing of DPPH radical scavenging activity during 45 days of storage (Figure 9).

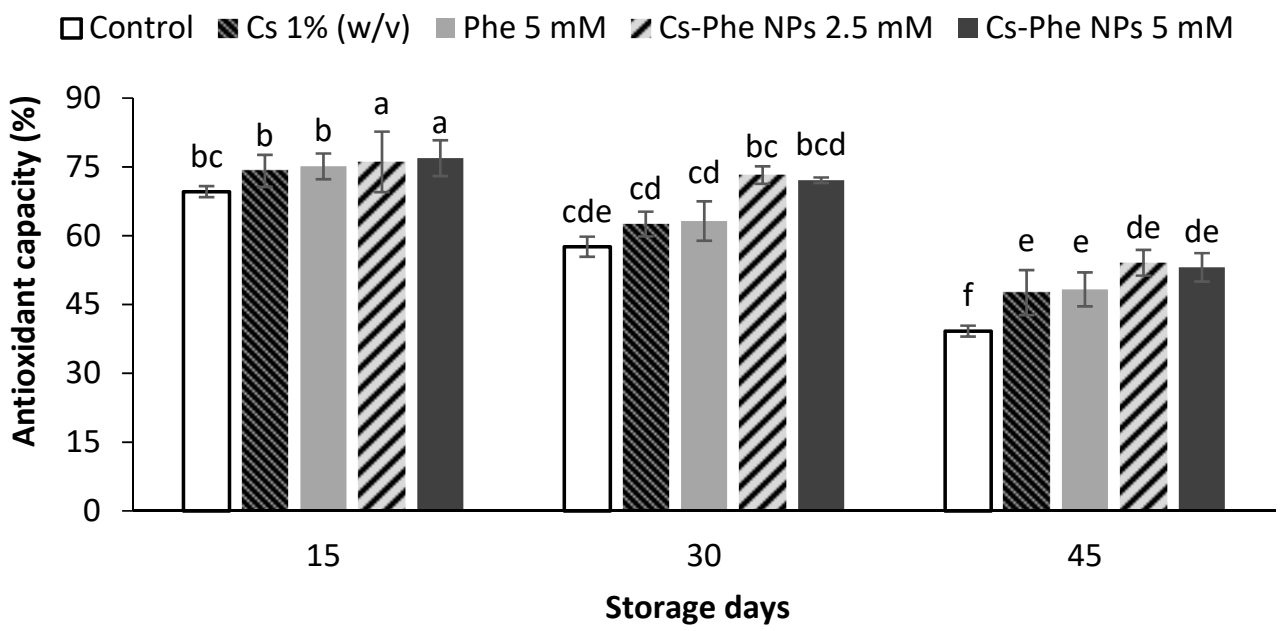

Figure 9. Effects of chitosan, phenylalanine, and chitosan-coated phenylalanine nanoparticles treatments on the antioxidant capacity of persimmon fruit during storage at $4{ }^{\circ} \mathrm{C}$ for 15,30 , and 45 days. Each value represents the mean \pm standard errors of three replications. Different letters indicate statistical differences using Duncan's multiple range tests at $P<0.05$ level.

Antioxidants are found in all fruit and may prevent some of the damage caused by free radicals by neutralizing them. These include carotenoid, phenol, flavonoid, vitamins A, C, and E, and CAT, SOD, and APX enzymes [76]. Gil et al. [77] have shown that eating a diet rich in fresh fruits and vegetables helps increase the levels of antioxidants and reduces the risk of deadly heart and brain diseases and cancers. Severe depletion of postharvest antioxidant compounds may be due to postharvest stress or low storage temperature. It seems that fruit coating using Cs-Phe NPs could maintain the antioxidant capacity of fruits during storage by reducing respiration and removing oxygen free radicals. Chitosan solution has been reported to increase the digestive potential of reactive oxygen species, leading to an increase in antioxidants in many fruits [74].

\section{Conclusions}

Our results demonstrate that 2.5 and $5 \mathrm{mM}$ Cs-Phe NPs treatments markedly alleviate chilling injury and retain eating quality in persimmon fruit during cold storage. The results of this study showed that solely chitosan and phenylalanine treatments had a relative effect on the preservation of firmness, antioxidant properties, and quality of persimmon fruit during cold storage, but the combined effect of these treatments was higher than any of them alone in increasing the shelf life of persimmon fruit and maintaining its quality and antioxidant properties. Furthermore, the results of this study showed that fruits treated with Cs-Phe NPs showed the highest amount of antioxidant activity and the lowest amount of MDA, $\mathrm{H}_{2} \mathrm{O}_{2}$, and chilling damage compared to control samples and other treatments during 45 days in cold storage. Thus, it could be concluded that Cs-Phe NPs treatments with concentrations of 2.5 and $5 \mathrm{mM}$ could be used in postharvest management to increase the shelf life and maintain the quality of persimmon fruit.

Author Contributions: Conceptualization, G.G.; methodology, F.N.; validation, V.R. and F.R.; investigation, F.N., V.R. and F.R.; writing-original draft preparation, F.N., S.F. and G.G.; writing—review and editing, M.P., G.G. and J.M.L. All authors have read and agreed to the published version of the manuscript. 
Funding: This research received no external funding.

Institutional Review Board Statement: Not applicable.

Informed Consent Statement: Not applicable.

Data Availability Statement: The data presented in this study are available on request from the corresponding author.

Conflicts of Interest: The authors declare no conflict of interest.

\section{References}

1. Besada, C.; Salvador, A. Postharvest biology and technology of persimmon. In Postharvest Biology and Technology of Temperate Fruits; Mir, S.A., Shah, M.A., Mir, M.M., Eds.; Springer International Publishing AG: Cham, Switzerland, 2018; pp. 371-393, ISBN 978-3-319-76843-4.

2. Khademi, O.; Zamani, Z.; Mostofi, Y.; Adib, J.; Ahmadi, A. Defining the suitable cold storage temperature for 'Karaj' persimmon. Acta Hortic. 2012, 934, 769-774. [CrossRef]

3. Arnal, L.; Besada, C.; Navarro, P.; Salvador, A. Effect of controlled atmospheres on maintaining quality of persimmon fruit cv. "Rojo Brillante". J. Food Sci. 2007, 73, S26-S30. [CrossRef] [PubMed]

4. Liamnimitr, N.; Thammawong, M.; Techavuthiporn, C.; Fahmy, K.; Suzuki, T.; Nakano, K. Optimization of bulk modified atmosphere packaging for long-term storage of 'Fuyu' persimmon fruit. Postharvest Biol. Technol. 2018, 135, 1-7. [CrossRef]

5. Khademi, O.; Zamani, Z.; Poor Ahmadi, E.; Kalantari, S. Effect of UV-C radiation on postharvest physiology of persimmon fruit (Diospyros kaki Thunb.) cv. "Karaj" during storage at cold temperature. Int. Food Res. J. 2013, 20, 247-253.

6. Woolf, A.B.; Ball, S.; Spooner, K.J.; Lay-Yee, M.; Ferguson, I.B.; Watkins, C.B.; Gunson, A.; Forbes, S.K. Reduction of chilling injury in the sweet persimmon "Fuyu" during storage by dry air heat treatments. Postharvest Biol. Technol. 1997, 11, 155-164. [CrossRef]

7. Salvador, A.; Arnal, L.; Monterde, A.; Cuquerella, J. Reduction of chilling injury symptoms in persimmon fruit cv. "Rojo Brillante" by 1-MCP. Postharvest Biol. Technol. 2004, 33, 285-291. [CrossRef]

8. Besada, C.; Llorca, E.; Novillo, P.; Hernando, I.; Salvador, A. Short-term high $\mathrm{CO}_{2}$ treatment alleviates chilling injury of persimmon cv. Fuyu by preserving the parenchyma structure. Food Control 2015, 51, 163-170. [CrossRef]

9. Besada, C.; Novillo, P.; Navarro, P.; Salvador, A. Effect of a low oxygen atmosphere combined with 1-MCP pretreatment on preserving the quality of "Rojo Brillante" and "Triumph" persimmon during cold storage. Sci. Hortic. 2014, 179, 51-58. [CrossRef]

10. Li, J.; Han, Y.; Hu, M.; Jin, M.; Rao, J. Oxalic acid and 1-methylcyclopropene alleviate chilling injury of 'Youhou' sweet persimmon during cold storage. Postharvest Biol. Technol. 2018, 137, 134-141. [CrossRef]

11. Besada, C.; Arnal, L.; Salvador, A. Improving storability of persimmon cv. Rojo Brillante by combined use of preharvest and postharvest treatments. Postharvest Biol. Technol. 2008, 50, 169-175. [CrossRef]

12. Yu, J.; Wang, D.; Geetha, N.; Khawar, K.M.; Jogaiah, S.; Mujtaba, M. Current trends and challenges in the synthesis and applications of chitosan-based nanocomposites for plants: A review. Carbohydr. Polym. 2021, 261, 117904. [CrossRef] [PubMed]

13. Ali, A.; Muhammad, M.T.M.; Sijam, K.; Siddiqui, Y. Potential of chitosan coating in delaying the postharvest anthracnose (Colletotrichum gloeosporioides Penz.) of Eksotika II papaya. Int. J. Food Sci. Technol. 2010, 45, 2134-2140. [CrossRef]

14. Wang, S.Y.; Gao, H. Effect of chitosan-based edible coating on antioxidants, antioxidant enzyme system, and postharvest fruit quality of strawberries (Fragaria $\times$ aranassa Duch.). LWT Food Sci. Technol. 2013, 52, 71-79. [CrossRef]

15. Luo, Y.; Wang, Q. Recent advances of chitosan and its derivatives for novel applications in food science. J. Food Process. Beverages 2013, 1, 1-13.

16. Sorrentino, A.; Gorrasi, G.; Vittoria, V. Potential perspectives of bio-nanocomposites for food packaging applications. Trends Food Sci. Technol. 2007, 18, 84-95. [CrossRef]

17. Eshghi, S.; Hashemi, M.; Mohammadi, A.; Badii, F.; Mohammadhoseini, Z.; Ahmadi, K. Effect of nanochitosan-based coating with and without copper loaded on physicochemical and bioactive components of fresh strawberry fruit (Fragaria $\times$ ananassa Duchesne) during storage. Food Bioprocess Technol. 2014, 7, 2397-2409. [CrossRef]

18. Kumar Patel, M.; Maurer, D.; Feygenberg, O.; Ovadia, A.; Elad, Y.; Oren-Shamir, M.; Alkan, N. Phenylalanine: A promising inducer of fruit resistance to postharvest pathogens. Foods 2020, 9, 646. [CrossRef]

19. Sogvar, O.B.; Rabiei, V.; Razavi, F.; Gohari, G. Phenylalanine alleviates postharvest chilling injury of plum fruit by modulating antioxidant system and enhancing the accumulation of phenolic compounds. Food Technol. Biotechnol. 2020, 58, 433-444. [CrossRef]

20. Seo, J.M.; Arasu, M.V.; Kim, Y.B.; Park, S.U.; Kim, S.J. Phenylalanine and LED lights enhance phenolic compound production in Tartary buckwheat sprouts. Food Chem. 2015, 177, 204-213. [CrossRef] [PubMed]

21. Portu, J.; Santamaría, P.; López-Alfaro, I.; López, R.; Garde-Cerdán, T. Methyl jasmonate foliar application to tempranillo vineyard improved grape and wine phenolic content. J. Agric. Food Chem. 2015, 63, 2328-2337. [CrossRef] [PubMed]

22. Ruffo Roberto, S.; Youssef, K.; Hashim, A.F.; Ippolito, A. Nanomaterials as alternative control means against postharvest diseases in fruit crops. Nanomaterials 2019, 9, 1752. [CrossRef] [PubMed]

23. Lustriane, C.; Dwivany, F.M.; Suendo, V.; Reza, M. Effect of chitosan and chitosan-nanoparticles on post harvest quality of banana fruits. J. Plant Biotechnol. 2018, 45, 36-44. [CrossRef] 
24. Resende, N.S.; Gonçalves, G.A.S.; Reis, K.C.; Tonoli, G.H.D.; Boas, E.V.B.V. Chitosan/cellulose nanofibril nanocomposite and its effect on quality of coated strawberries. J. Food Qual. 2018, 2018, 1727426. [CrossRef]

25. Meena, M.; Pilania, S.; Pal, A.; Mandhania, S.; Bhushan, B.; Kumar, S.; Gohari, G.; Saharan, V. Cu-chitosan nano-net improves keeping quality of tomato by modulating physio-biochemical responses. Sci. Rep. 2020, 10, 21914. [CrossRef] [PubMed]

26. Ding, C.K.; Wang, C.Y.; Gross, K.C.; Smith, D.L. Jasmonate and salicylate induce the expression of pathogenesis-related-protein genes and increase resistance to chilling injury in tomato fruit. Planta 2002, 214, 895-901. [CrossRef]

27. Xing, Y.; Yang, H.; Guo, X.; Bi, X.; Liu, X.; Xu, Q.; Wang, Q.; Li, W.; Li, X.; Shui, Y.; et al. Effect of chitosan/nano-TiO 2 composite coatings on the postharvest quality and physicochemical characteristics of mango fruits. Sci. Hortic. 2020, 263, 109135. [CrossRef]

28. Nilsson, T. Effects of ethylene and 1-MCP on ripening and senescence of European seedless cucumbers. Postharvest Biol. Technol. 2005, 36, 113-125. [CrossRef]

29. Hodges, D.M.; DeLong, J.M.; Forney, C.F.; Prange, R.K. Improving the thiobarbituric acid-reactive-substances assay for estimating lipid peroxidation in plant tissues containing anthocyanin and other interfering compounds. Planta 1999, 207, 604-611. [CrossRef]

30. Patterson, B.D.; MacRae, E.A.; Ferguson, I.B. Estimation of hydrogen peroxide in plant extracts using titanium (IV). Anal. Biochem. 1984, 139, 487-492. [CrossRef]

31. Taira, S. Astringency in persimmon. In Modern Methods of Plant Analysis; Linskens, H.F., Jackson, J.F., Eds.; Springer: Berlin/Heidelberg, Germany, 1996; pp. 97-110. ISBN 978-3-642-79662-3.

32. Wang, Z.F.; Ying, T.J.; Bao, B.L.; Huang, X.D. Characteristics of fruit ripening in tomato mutant epi. J. Zhejiang Univ. Sci. B 2005, 6, 502-507. [CrossRef] [PubMed]

33. Nguyen, T.B.T.; Ketsa, S.; van Doorn, W.G. Relationship between browning and the activities of polyphenol oxidase and phenylalanine ammonia lyase in banana peel during low temperature storage. Postharvest Biol. Technol. 2003, 30, 187-193. [CrossRef]

34. Zhang, Z.; Huber, D.J.; Rao, J. Antioxidant systems of ripening avocado (Persea americana Mill.) fruit following treatment at the preclimacteric stage with aqueous 1-methylcyclopropene. Postharvest Biol. Technol. 2013, 76, 58-64. [CrossRef]

35. Bradford, M.M. A rapid and sensitive method for the quantitation of microgram quantities of protein utilizing the principle of protein-dye binding. Anal. Biochem. 1976, 72, 248-254. [CrossRef]

36. Dehghan, G.; Khoshkam, Z. Tin(II)-quercetin complex: Synthesis, spectral characterisation and antioxidant activity. Food Chem. 2012, 131, 422-426. [CrossRef]

37. Jafari, H.; Mahdavinia, G.R.; Kazemi, B.; Ehrlich, H.; Joseph, Y.; Rahimi-Nasrabadi, M. Highly efficient sunitinib release from pH-responsive mHPMC@Chitosan core-shell nanoparticles. Carbohydr. Polym. 2021, 258, 117719. [CrossRef] [PubMed]

38. Zheng, X.; Xu, K.; Wang, Y.; Shen, R.; Wang, Q. Study of hydrogen explosion control measures by using l-phenylalanine for aluminum wet dust removal systems. RSC Adv. 2018, 8, 41308-41316. [CrossRef]

39. Bagheri, M.; Esna-Ashari, M.; Ershadi, A. Effect of postharvest calcium chloride treatment on the storage life and quality of persimmon fruits (Diospyros kaki Thunb.) cv. 'Karaj'. Int. J. Hortic. Sci. Technol. 2015, 2, 15-26.

40. Emamifar, A.; Bavaisi, S. Nanocomposite coating based on sodium alginate and nano-ZnO for extending the storage life of fresh strawberries (Fragaria $\times$ ananassa Duch.). J. Food Meas. Charact. 2020, 14, 1012-1024. [CrossRef]

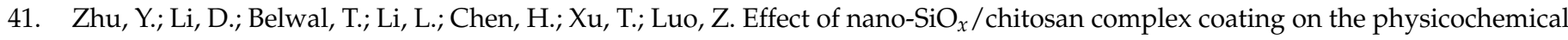
characteristics and preservation performance of green tomato. Molecules 2019, 24, 4552. [CrossRef] [PubMed]

42. Dong, F.; Li, S.; Jin, C.; Liu, Z.; Zhu, K.; Zou, H.; Wang, X. Effect of nanocellulose/chitosan composite coatings on cucumber quality and shelf life. Toxicol. Environ. Chem. 2016, 98, 450-461. [CrossRef]

43. Gao, P.; Zhu, Z.; Zhang, P. Effects of chitosan-glucose complex coating on postharvest quality and shelf life of table grapes. Carbohydr. Polym. 2013, 95, 371-378. [CrossRef]

44. Nguyen, V.T.B.; Nguyen, D.H.H.; Nguyen, H.V.H. Combination effects of calcium chloride and nano-chitosan on the postharvest quality of strawberry (Fragaria $\times$ ananassa Duch.). Postharvest Biol. Technol. 2020, 162, 111103. [CrossRef]

45. Salvador, A.; Arnal, L.; Besada, C.; Larrea, V.; Hernando, I.; Pérez-Munuera, I. Reduced effectiveness of the treatment for removing astringency in persimmon fruit when stored at $15^{\circ} \mathrm{C}$ : Physiological and microstructural study. Postharvest Biol. Technol. 2008, 49 , 340-347. [CrossRef]

46. Ferree, D.C.; Warrington, I.J. Apples Botany, Production and Uses; CABI Publishing: Wallingford, UK, 2003.

47. Ali, A.; Muhammad, M.T.M.; Sijam, K.; Siddiqui, Y. Effect of chitosan coatings on the physicochemical characteristics of Eksotika II papaya (Carica papaya L.) fruit during cold storage. Food Chem. 2011, 124, 620-626. [CrossRef]

48. Youssef, K.; de Oliveira, A.G.; Tischer, C.A.; Hussain, I.; Roberto, S.R. Synergistic effect of a novel chitosan/silica nanocompositesbased formulation against gray mold of table grapes and its possible mode of action. Int. J. Biol. Macromol. 2019, 141, $247-258$. [CrossRef]

49. Vargas, M.; Albors, A.; Chiralt, A.; González-Martínez, C. Quality of cold-stored strawberries as affected by chitosan-oleic acid edible coatings. Postharvest Biol. Technol. 2006, 41, 164-171. [CrossRef]

50. Xing, Y.; Li, X.; Xu, Q.; Yun, J.; Lu, Y.; Tang, Y. Effects of chitosan coating enriched with cinnamon oil on qualitative properties of sweet pepper (Capsicum annuum L.). Food Chem. 2011, 124, 1443-1450. [CrossRef]

51. Xu, W.T.; Peng, X.-L.; Luo, Y.B.; Wang, J.-A.; Guo, X.; Huang, K.L. Physiological and biochemical responses of grapefruit seed extract dip on "Redglobe" grape. LWT Food Sci. Technol. 2009, 42, 471-476. [CrossRef] 
52. Sofo, A.; Dichio, B.; Xiloyannis, C.; Masia, A. Effects of different irradiance levels on some antioxidant enzymes and on malondialdehyde content during rewatering in olive tree. Plant Sci. 2004, 166, 293-302. [CrossRef]

53. Song, H.; Yuan, W.; Jin, P.; Wang, W.; Wang, X.; Yang, L.; Zhang, Y. Effects of chitosan/nano-silica on postharvest quality and antioxidant capacity of loquat fruit during cold storage. Postharvest Biol. Technol. 2016, 119, 41-48. [CrossRef]

54. Ali, S.; Khan, A.S.; Malik, A.U.; Shaheen, T.; Shahid, M. Pre-storage methionine treatment inhibits postharvest enzymatic browning of cold stored 'Gola' litchi fruit. Postharvest Biol. Technol. 2018, 140, 100-106. [CrossRef]

55. Baig, S.; Azizan, A.H.S.; Raghavendran, H.R.B.; Natarajan, E.; Naveen, S.; Murali, M.R.; Nam, H.Y.; Kamarul, T. Effect of chitosan nanoparticle-loaded thymus serpyllum on hydrogen peroxide-induced bone marrow stromal cell damage. Stem Cells Int. 2019, 5142518. [CrossRef]

56. Attia, M.S.; El-Sayyad, G.S.; Abd Elkodous, M.; Khalil, W.F.; Nofel, M.M.; Abdelaziz, A.M.; Farghali, A.A.; El-Batal, A.I.; El Rouby, W.M.A. Chitosan and EDTA conjugated graphene oxide antinematodes in Eggplant: Toward improving plant immune response. Int. J. Biol. Macromol. 2021, 179, 333-344. [CrossRef] [PubMed]

57. Sheikhalipour, M.; Esmaielpour, B.; Behnamian, M.; Gohari, G.; Giglou, M.T.; Vachova, P.; Rastogi, A.; Brestic, M.; Skalicky, M. Chitosan-selenium nanoparticle (Cs-Se NP) foliar spray alleviates salt stress in bitter melon. Nanomaterials 2021, 11, 684. [CrossRef] [PubMed]

58. Khademi, O.; Mostofi, Y.; Zamani, Z.; Fatahi, R. The effect of deastringency treatments on increasing the marketability of persimmon fruit. In Proceedings of the VI International Postharvest Symposium, Antalya, Turkey, 8-12 April 2009; Acta Horticulturae. International Society for Horticultural Science: Korbeek-Lo, Belgium, 2010; Volume 877, pp. 687-692.

59. Xue, J.; Huang, L.; Zhang, S.; Sun, H.; Gao, T. Study on the evaluation of carboxymethyl-chitosan concentration and temperature treatment on the quality of "Niuxin" persimmon during cold storage. J. Food Process. Preserv. 2020, 44, e14560. [CrossRef]

60. Egert, M.; Tevini, M. Influence of drought on some physiological parameters symptomatic for oxidative stress in leaves of chives (Allium schoenoprasum). Environ. Exp. Bot. 2002, 48, 43-49. [CrossRef]

61. Zhou, C.; Zhao, D.; Sheng, Y.; Tao, J.; Yang, Y. Carotenoids in fruits of different persimmon cultivars. Molecules 2011, 16, 624-636. [CrossRef]

62. González-Saucedo, A.; Barrera-Necha, L.L.; Ventura-Aguilar, R.I.; Correa-Pacheco, Z.N.; Bautista-Baños, S.; Hernández-López, M. Extension of the postharvest quality of bell pepper by applying nanostructured coatings of chitosan with Byrsonima crassifolia extract (L.) Kunth. Postharvest Biol. Technol. 2019, 149, 74-82. [CrossRef]

63. Lei, F.; Liu, F.; Yuan, F.; Gao, Y. Impact of chitosan-EGCG conjugates on physicochemical stability of $\beta$-carotene emulsion. Food Hydrocoll. 2014, 39, 163-170. [CrossRef]

64. Siddiqui, Z.A.; Parveen, A.; Ahmad, L.; Hashem, A. Effects of graphene oxide and zinc oxide nanoparticles on growth, chlorophyll, carotenoids, proline contents and diseases of carrot. Sci. Hortic. 2019, 249, 374-382. [CrossRef]

65. Pasquariello, M.S.; Di Patre, D.; Mastrobuoni, F.; Zampella, L.; Scortichini, M.; Petriccione, M. Influence of postharvest chitosan treatment on enzymatic browning and antioxidant enzyme activity in sweet cherry fruit. Postharvest Biol. Technol. 2015, 109, 45-56. [CrossRef]

66. Ke, D.; Saltveit, M.E. Plant hormone interaction and phenolic metabolism in the regulation of russet spotting in iceberg lettuce. Plant Physiol. 1988, 88, 1136-1140. [CrossRef] [PubMed]

67. Cantos, E.; Tudela, J.A.; Gil, M.I.; Espín, J.C. Phenolic compounds and related enzymes are not rate-limiting in browning development of fresh-cut potatoes. J. Agric. Food Chem. 2002, 50, 3015-3023. [CrossRef]

68. Jiang, Y. Role of anthocyanins, polyphenol oxidase and phenols in lychee pericarp browning. J. Sci. Food Agric. 2000, 80, 305-310. [CrossRef]

69. Sathiyabama, M.; Indhumathi, M.; Muthukumar, S. Chitosan nanoparticles loaded with thiamine stimulate growth and enhances protection against wilt disease in Chickpea. Carbohydr. Polym. 2019, 212, 169-177.

70. Kitazuru, E.R.; Moreira, A.V.B.; Mancini-Filho, J.; Delincée, H.; Villavicencio, A.L.C.H. Effects of irradiation on natural antioxidants of cinnamon (Cinnamomum zeylanicum N. ). Radiat. Phys. Chem. 2004, 71, 39-41. [CrossRef]

71. Tajvar, Y.; Ghazvini, R.F.; Hamidoghli, Y.; Sajedi, R.H. Antioxidant changes of Thomson navel orange (Citrus sinensis) on three rootstocks under low temperature stress. Hortic. Environ. Biotechnol. 2011, 52, 576-580. [CrossRef]

72. Tian, S.P.; Li, B.Q.; $\mathrm{Xu}, \mathrm{Y}$. Effects of $\mathrm{O}_{2}$ and $\mathrm{CO}_{2}$ concentrations on physiology and quality of litchi fruit in storage. Food Chem. 2005, 91, 659-663. [CrossRef]

73. Junmatong, C.; Faiyue, B.; Rotarayanont, S.; Uthaibutra, J.; Boonyakiat, D.; Saengnil, K. Cold storage in salicylic acid increases enzymatic andnon-enzymatic antioxidants of Nam Dok Mai No. 4 mango fruit. Sci. Asia 2015, 41, 12-21. [CrossRef]

74. Yu, Y.; Zhang, S.; Ren, Y.; Li, H.; Zhang, X.; Di, J. Jujube preservation using chitosan film with nano-silicon dioxide. J. Food Eng. 2012, 113, 408-414. [CrossRef]

75. Saharan, V.; Kumaraswamy, R.V.; Choudhary, R.C.; Kumari, S.; Pal, A.; Raliya, R.; Biswas, P. Cu-chitosan nanoparticle mediated sustainable approach to enhance seedling growth in maize by mobilizing reserved food. J. Agric. Food Chem. 2016, 64, 6148-6155. [CrossRef] [PubMed]

76. Van de Velde, F.; Tarola, A.; Güemes, D.; Pirovani, M. Bioactive compounds and antioxidant capacity of camarosa and selva strawberries (Fragaria $\times$ ananassa Duch.). Foods 2013, 2, 120-131. [CrossRef] [PubMed]

77. Gil, M.I.; Tomas-Barberan, F.A.; Hess-Pierce, B.; Holcroft, D.M.; Kader, A.A. Antioxidant activity of pomegranate juice and its relationship with phenolic composition and processing. J. Agric. Food Chem. 2000, 48, 4581-4589. [CrossRef] [PubMed] 